\title{
Doxa in Indonesian Literature: Practice of Wiji Thukul's Literature In Pierre Bourdieu's Perspective of Cultural Production Arena
}

\author{
Panji Kuncoro Hadi ${ }^{1}$, Suyitno $^{2}$, Retno Winarni ${ }^{3}$, Nugraheni Eko Wardani ${ }^{4}$ \\ \{panjikuncorohadi200971@gmail.com ${ }^{1}$, yitsuyitno52@gmail.com ${ }^{2}$, retnowinarni@staff.uns.ac.id ${ }^{3}$. \\ nugraheniekowardani 99@yahoo.co.id $\left.{ }^{4}\right\}$
}

Sebelas Maret University, Surakarta, Indonesia ${ }^{1,2,3,4}$

\begin{abstract}
The purpose of this study is to explain doxa in Indonesian literature during the New Order era limited for the period of 1980-1998. Doxa shows the existence of the construction of Indonesian literary arena. Doxa is a set of fundamental beliefs or dogmas. Doxa also means as a belief which is accepted as it is and never been questioned. Doxa directs a person's perspective in perceiving the world or arena in which it is located. Pierre Bourdieu's theory of Cultural production Arena is used to explain the existence of doxa in the construction of the Indonesian literary arena. The library research or literary study is used to collect the data related to the existence of doxa in Indonesian literary arena during the time and at times of Wiji Thukul's literary practice. Pierre Bourdieu's cultural production arena theory is used to analyze the data in the form of texts related to the subject matter obtained from books, magazines, newspapers, and writings. The results showed that 1) the Indonesian literary arena was dominated by universal literary groups. Instruments of mastery through doxa and support from the government (state) of the new order; 2) the opposing group and the plaintiff are the contextual literary group along with other literary possibilities; 3 ) Wiji Thukul started his leterary practice when the universal literary doctrine was very strong which made him fail.
\end{abstract}

Keywords: Doxa, Indonesian Literature, WijiThukul, Pierre Bourdieu, Cultural production Arena.

\section{Introduction}

The approach in literature is ultimately a sociological approach. Most research only depended the approch on one object or only analyze their intrinsic or extrinsic as pects. For example, a specific approach to the work, author, or only the reader.

In fact, literature is a sociologicalphenomenon. For this reason, although the three aspects above are considered complete, further study is certainly needed. For example, reader could mean as consumer of the literature or it could mean as someone who givemeaning to the literarure (critics, publishers, literary figures). Thus, the approach in the perspective of literature should be in the arena of production especially an arena of cultural production, beside involving the three approaches mentioned above.

Bourdieu[1]s tates that the analysis of literature or art should be conducted together between internal and external analysis. Analysis of literary works must also consider the social conditions of production. Therefore, analysis on literature is an analysis of the literary arena as it is a complexity which contains a series of practices of opposition, competition, and control involving literary agents.

Bourdieu described the complexity of the literary arena as an arena of strength as well as an arena of struggle to transform or maintain theexis ting power relations. In this struggle, each agent involves its strengths (specific capital) obtained from previous struggles through strategies whose orientation depends on their respective positions in the power relations [2]. Furthermore, Bourdieu reinforced by calling the arena of cultural production can only be fully understood when it is seen as an arena of competition for the monopoly on the legitimate use of symbolic violence[3].

Symbolic power is the power to change and create reality in which changing and creating something that is recognized, approved and als o valid. Symbolic power to make people see and believe, to strengthen or change the way in which people view and change the world[4]. Bourdieu explains the process of the occurrence or mechanism of this symbolic power through 'doxa', which is "a set of fundamental beliefs which does not need to be explicitly shown, as if it is a dogma[5].

In other words, doxa is the perspective of the ruler or those who are dominant which considered as the pers pective of the whole society. Society no longer criticize the pers pective of the authorities. The authorities' perspective is us ually sloganistic, simple, popular, and easily understood by many people, although conceptually that perspective contain many errors. 
Doxa works through language. Bourdieu believes that language is a symbol of power. Symbolic domination and power structure that exists in society hidden in the language. For example, the grammar used by someone reflects his socioeconomic class in society.

Doxa applies in the arena. The actor is the dominant literary who dominates the arena with his doxas. Including in the Indonesian literary arena which demands a rule where someone is not considerd as a writer if the person does not received recognition frominstitutions, festivals, and senior writers. Bourdieu in [6] states that the status of 'litterateur' is a label as well as a complex process that occurs within a certain scope called 'arena'. Someone who writes and publis hes novels does not automatically become a litterateur because the status of 'litterateur' is actually given by certain parties in the literary arena.

Wiji Thukulentered the arena When the universal literary doxa was going on very strongly. He is a writer who was born in Sorogenen village, Solo, August 26, 1963. Wiji Thukul's real name is Wiji Widodo. Additional words or names of Thukul were given by Cempe Lawu Warta, Wiji Thukul's Theater Teacher at Jag at Theater. Wiji Thukul hims elf had added the word or name Wijay a to become Wiji Thukul Wijaya, but he was teased by his friends as taken a bourgeois name[7].

Wiji Thukul was born from a poor family. He is the first child of 3 brothers. His father is Kemis Harjos uwito who worked as padicap driver while his mother, Sayem, is a seas oned chicken seller. Wiji Thukul's younger brother is Wahyu Susilo and his second brother is Nasri. Wiji Thukulmarried Dyah Sujirah or Sipon in 1988 and had two children, Fitri Nganti Wani and Fajar Merah [7].

Wiji Thukul started writing poetry since elementary school. Graduating from elementary school in 1977, Wiji Thukul continued his education at SMP Negeri 8 Solo. While attending school, Wiji Thukul became a cinema ticket scalper. Graduating from junior high school, Wiji Thukul went on to Karawitan Indonesia Middle School (SMKI) Solo, majoring in dance, but did not graduate ordrop out in 1982. He sold news papers and worked in a furniture company as a polish and active at Jagat Theater (short for Jejibahan of Agawe Genepe Akal Tumindak) or Central Jagalan Theater[7].

Based on the background above, the problemin this rese arch can be formulated as doxa in Indonesian literature, is there any resistance orheterodoxis m to Indonesian literary doxa and how does doxa in Indonesian literature influence Wiji Thukul's literary practice. The theory used to help explain the above problem is Pierre Bourdieu's cultural production arena theory:

In his theory of the arena, [4]states that the literary arena is a separate social universe with its own law of functioning. Seperated from the laws of political and economic functioning (a separate social universe having its own laws of functioning independent of those of politics and the economy). Which means that the literary arena has its own rules (autonomy). The literary arena is also seperated fromand does notcomply to the subject to the political arena and the economic arena.

According to [4] the literary arena is a kind of site analys is which establishes the position of literature in the arena. For example, positions that correspond to one particular genre. Novel corresponds to its genre subcategories such as community novels (Roman Mondain) or popular nov els. Positions are also subjectively defined by a systemof distinctive properties through which one position can be synchronized among other positions. The existence of each position and the determinations that carried to theperson who occupies depend on other positions that form the arena.

Bourdieu also explained that the structure of the arena, the space of positions in the form of capital distribution structures of specific properties that govern success in the arena and win external profits or specific profits (such as literary prestige) which put at stake therein. Thus, the literary arena is also a place for struggles that risk the power to impose a dominant definition of the author. The main bet in the literary struggle is the monopoly of literary legitimacy [3].

Furthermore, according to [8], in the literary arena there is always a change caused by 1) space taking position, a place where the arena of art or literature is expres sed or a series of structured manifestations of s ocial agents involved in the literary arena or art. Besides literary or artistic works, there are also political actions or decisions, manifestos or polemics. Each position is determined by a space of possibilities that are objectively recognized as problematic in the form of taking actual or potential positions according to various positions available; 2) the space of possibilities, there is always a change in position taking in every literary arena, even when that position remains identical as there is always a change in the universe of choices simultaneously offered to be chosen by producers and consumers.

Based on the statement above, it can be concluded that the arena is a struggle or competition for certain positions. Therefore, an agent can move fromone position to another. The struggle for the transfer of this position requires a series of actions or practices based on and influenced by capital (what the agent has), strategies including his life history. 


\section{Rese arch Methodology}

Based on the data and data explanation methods, this research is a qualitative descriptive study. According to [9], qualitative research is exploratory research, which is exploring and understanding the meaning that comes from social or humanitarian problems. Although this research is a literary research, but the paradigm remains in keeping with Creswell's statement above, which is understanding social and humanitarian issues.

The data for this reserach is collected through library methods or literature study. The data analysis method used in this study is adapted to the method in Pierre Bourdieu's cultural production arena theory, namely intrinsic and extrinsic analysis simultaneously. The analysis starting from production, consumption, and circulation. Sources of data for this study were obtained frominterviews and literature. The data is in the form of text related to doxa in Indonesian literature and Wiji Thukul's literary practice.

\section{Result And Discussion}

The Indonesian literary arena is dominated by universal literature through instruments of doxa and supported by the government (state) of the new order. Below is a statement about the power of universal literature and its doxa in the Indonesian literary arena.

Where does "literature" come from? In Indonesia this time we can find two large groups of ans wers. The first group will answer "from the mind". The second, "from social life". The first generally embraced the view of "universal literature". The first view is the view that is currently the most powerful or influential in Indonesia [10].

The above statement implies that the construction of the Indonesian literary arena in the 1980s was dominated by universal literature through its doxa where literature is a product of mind. As opposed to universal literature is contextual literature with its heterodoxy or contradiction where literature is a product of social life.The power of universal literary is supported by its literary figures such as Budi Darma who stated that: "literature is born from inner wealth"[10]. His statement is in line with the previous statement.

The power of universal literary also runs through art institutions such as the arts council. The following is evidence that the arts council such as the Jakarta Arts Council supported the universal literary by awarding one of its figure in one of its activities. Thus, universal literary groups presented an ward toliterateurs or writers in universal groups.

... this is not a "coincidence" that the 1983 literary prize from DKJ was given to writers such as Sapardi Djoko Damono and BudiDarma who were more or less in agreement with the orien tation of the literary values of the DKJ board management. [10].

In addition to doxa and its figures, as well as through the arts ins titutions, universal literature also has a specific literary and cultural mass media to spread and preserve its power through its doxa. The intended media is the literary magazine called "Horizon". The statement below shows that the Horizon played a role in politic through its symbolic power.

Regarding the Horizon magazine as a universal literary magazine has been revealed by Fuad Has san through [11] that:

Indonesian literature which published in the Horizon magazine is purple. Which means that it discussed a lot about one's personal feelings. social themes hardly emerge despite the fact that a terrible social and political upheaval had occurred at the time which is the transition of the political regime from the Sukarno era to the Soeharto era.

The statement implies that the literary works publis hed by the Horizon magazine are mostly personal themes or in the termcalled by Fuad Has an as "purple". Social themes hardly appeared. This further shows the government's position in viewing Indonesian literature where the government places universal literature as official literature, while literature with the social themes is forbidden as it is usually criticizes the government.

Regarding government financial support for the Horizon magazine was stated by Jamal D Rahman (Head of the Horizon Magazine) in an interview where he stated that the goverment provided financial support for the cost of publishing. Although the funds were sometimes given sometimes not. The government, especially the provincial government also provides financial support for arts institutions such as the arts council. Most art activities are always supported by the government funds. Therefore, the prizes or awards is impossible to be given to social literature whose contents are about criticism to the government.

In addition to universal literature, the construction of the Indonesian literary arena in the 1980s was also formed or constructed by contextual literature. Basically, this contextual literature is a strong "opponent" of univers al literature. One as pect that makes contextual literature a strong contender of universal literature is due 
to the initiator of contextual literature is known as an influential figure in Indonesia, especially in the social, political, and artistic aspects, especially in literary. The figure is Arief Budiman.

Arief Budiman in [12] states that there is domination of thought in Indonesian literature. That resulted in the development of unhealthy Indonesian literature. The domination of thought in the form of aesthetism, which is the thought of literature as an individual phenomenon and aesthetic value and not as a symptom of society.

In line with the above opinion,[13] states that literature which is in the camp of "pure literature" refers to puritans and even trapped in a hedonistic, egoistic, and defaistic attitude, without desire to know about what happened to their brothers and sisters who suffered from the system they enjoyed. This attitude resulted in Indonesian literature being isolated from itself and the surrounding community.

The emergence of contextual literature began with a declaration which was pioneered by [10], [11]. According to both, the development of Indonesian literature all those times has been unhealthy and stagnant because it was dominated by universal literature which is too individualistic and tends to reject the relationship between literature and social politics. In the 1980s Indonesian literary construction was built from two "groups", Universal literary groups and contextual literary groups [10]. Ariel added that universal literary groups are in power and very influential in Indonesia.

In addition to universal literature and contextual literature, there are other possible literary spaces. However, only universal literature received official recognition fromthe government. There are some space of possibilities that can be "worked on" by other artists and writers such as popular literature and regional literature. The following is a table of the positions of literary possibilities in the construction of Indonesian literary arena and their opposition to universal literature.

Table 1: Indonesian Literature Arena

\begin{tabular}{lcccc}
\hline & $\begin{array}{c}\text { Authorized } \\
\text { Literature }\end{array}$ & Separated & Underestimated & Forbidden \\
\hline Universal Literature & $\sqrt{ }$ & - & - & - \\
\hline Contextual Literature & - & - & - & $\sqrt{ }$ \\
\hline Local Literature & - & $\sqrt{ }$ & - & - \\
\hline Popular Literature & - & - & - & $\sqrt{ }$ \\
\hline Wiji Thukul's & - & & & \\
Literature & & & & \\
\hline
\end{tabular}

According to [8], changes are always occur in literary arena due to (1) position taking, which occurs where the arena of art or literature is expressed or a series of structured manifestations of social agents involved in the literary or artistic arena; and (2) the space of possibilities, which occurs in the literary arena every time position taking occurs, even when the position remains identical as there is always a change in the universe of choices which simultaneously offered to be chosen by producers and consumers.

The above table is a development of [10] statement in page 4-7 that there are four Indonesian literatures, namely (1) literature that is "Authorized / validated"; (2) "forbidden" literature; (3) "underestimated" literature; and (4) "separated" literature. Literature that is "authorized / validated" tends to be apolitical and hegemonic. Authorized or validated literature is a literature which is developed with conceptual definitions, dominant study and historical writing and examples of literary works that are considered "legitimate" or "peaks". Such literature received the highest attention and appreciation in society. In addition, it also received legality in schools, seminars, scientific works, and can be found in bookshops with "literature" label.

It can be analyzed based on the abovetable that 1) universal literature receives "official" label from the government;2) contextual literature is prohibited by the government; 3) regional / local literature is separated from Indonesian literature;4) popular literature is underestimated; 5) literature by Wiji Thukul is prohibited by the government. In fact, Wiji Thukul's literature is too far from being authorized by the government. Wiji Thukul's poems are not only underestimated but also forbidden. Due to the fact that universal literature is authorized by the government, what is meant by national literature or Indonesian literature is actually universal literature.

Thus, the table above also explains the position of Indonesian literature in terms of government interests. The government with a financing model through ins titutions such as arts councils and schools, declares its symbolic poweror its doxa. Including through its literary agents, the governmentappointed writers who were given legitimate status. The government through its power mediators als o provides literary works to be read and appreciated in schools. Thus, it is clear that universal literature is highly recognized by the government while contxtual literature is prohibited. Contextual literature is considered not in accordance with the authority of the government and even tends to criticize the government.

Wiji Thukul appeared or practiced literature when the universal literary doxa was strong which made him failed. The following is the first Wiji Thukul's literary practice data when he was still adopting the 
univers al literature. Hanindawan, Poetry Room Caretaker at Rasitania Radio and Gidag GidigTheater Solo and Tinuk (Hanindawan's colleague, also Poetry Roomcaregiver on Radio Rasitania) witnessed Wiji Thukul's early poems which were still in religious romantic subgroups: "As most young poets of thosetimes, Thukul's thoughts are so stunned by poems that are religious afterthought, "said Tinuk, who was then a student at the Faculty of Literature at Sebelas Maret University, Surakarta [7].

The statement above illustrates that Wiji Thukul's early literary practice was under the influence of universal literary or Indonesian literature. Wiji Thukul's literary practices under the influence of universal literary or Indonesian literature did notreceive wider recognition. WijiThukuldid not receive recognition from senior national literary figures. Wiji Thukul's poems were not published in the mainstream mass media such as Kompas newspaper or Horizon magazine. Jamal D. Rahman, the head of Horison magazine who is also a national literary figure, stated that poemby Wiji Thukul was never published in Horizon magazine. Due to the fact that his poems were not accepted in the national literary arena, Wiji Thukul changed his poetic theme and style.

Table 2: Changing the Themeand Style of Poem (Literary Practice) Wiji Thukul

Wiji Thukul's Poem under Universal or Indonesian Puisi Wiji Thukul dalam Melawan Doksa Sastra Universal
Literarure Doxa atau Sastra Indonesia

\author{
Clock \\ Do not need to be surprised \\ Turn the clock will make you \\ The old story which alway dumb \\ Spread the jungle of new questions
}

angke, 9 March 83

\author{
The Grassroot Song \\ Road are widened \\ We are driven away \\ Set up villages \\ Evicted \\ We moved around \\ Stuck on the walls \\ Pulled out \\ Thrown \\ We are grass \\ We need soil \\ Listen! \\ Let joun us \\ To become the nightmare of the President!
}

July 1988

Both poems used different language, although the difference is graded. His move from universal literary to social criticism doxa was subtle. The theme of the poem entitled "Clock" is different from "The Grassroot Song". The poem "Clock" has religious theme. Wiji Thukul describes the past and present life connected with the clock methaphorically. Yesterday's life and present life are ontologically a matter of time. The poem "The Grassroot Song" has a social criticis m theme. Describing the poor who have no more land to live. Furthermore, the poor gathered to protest the president.

Due to unrecognization, Wiji Thukul changed his literary position to social criticis mpoetry. His capital is his habitus as a poor community. In the course of its practice Wiji Thukul indeed received recognition from fellow social literary groups, but receive rejection from universal literary figures.

Wiji Thukul brought his social criticism poems as his capital to enter the political arena (political parties). Buthe had to deal with the power of the New Order government. Wiji Thukul was kidnapped and eliminated by the New Order government because of his activities in political parties.

In his literary practice, when Indonesian literary doxa is dominant, Wiji Thukul conducted three "interruptions", first interruptions related to Indonesian literary doxa. There are two interruptions in Indonesian literary doxa, namely interruptions in the language used by Indonesian literature in general, and interruptions in the choice of Indonesian literary themes. The third interruption conducted by Wiji Thukul is on the sociopolitical conditions during the New Order government. The socio-political conditions in the New Order era which did not favor the lower clas ses became the themes chosen by Wiji Thukul while at the same time showing his position in Indonesian literature. Below is the marker or doxa and heterodoxa in the Indonesian literary arena.

Table 3: Doxa and Heterodoxa of Indonesia

\begin{tabular}{|c|c|c|c|c|}
\hline Universal Literature & Contextual Literature & $\begin{array}{c}\text { Regional/Local } \\
\text { Literature }\end{array}$ & Popular Literature & $\begin{array}{l}\text { Wiji Thukul's } \\
\text { Literature }\end{array}$ \\
\hline $\begin{array}{l}\text { Language Theme } \\
\text { Acrobat in Cross }\end{array}$ & Social Criticism & $\begin{array}{l}\text { Local Language. } \\
\text { Local theme }\end{array}$ & $\begin{array}{l}\text { Adoleschent Theme } \\
\text { Simple }\end{array}$ & $\begin{array}{l}\text { Criticism as tolls for } \\
\text { Resistance }\end{array}$ \\
\hline
\end{tabular}


Study.

Example; Sufi

Literature

The table above illus trates Doxa and heterod oxa published by each adherent of literaryis m. Univers al literature is literature with the ability to make a doxa. Contextual literature, local literature, popular literature, and Wiji Thukul's literature are hegemonized in the position of universal literary doxa. There is heterodoxa when there is resistance.

The only problemis that heterodoxis mor res is tance or questioning the doxa must deal with orthodoxy, an explicit thought of defending or try to maintain structure and rules in the arena. At that point in the Indonesian literary arena, universal literature is always the winner. According to Bourdieu [14] the process of symbolic power occurs when the autonomy of the arena weakens to allow the emergence of another thought conveyed by agents in the arena to question, challenge, or even replace the doxa called heterodox.

\section{Conclusion}

In the 1980s the Indonesian literary arena was dominated by universal literature through the instrument of doza and support from the government (state) of the new order. As a result, the position of literature and writers who without the support of the government is not developed and even there are some literatures and writers that are prohibited by the government. Wiji Thukul is one of the "victims" of the doxa published by univers al literary groups working with the government. The universal literary doxa becomes the Indonesian literary doxa. Because universal literature was actually iauthorized by the government (power).

The group that opposes universal literature is contextual literature and other possible spaces of literary. The fact that universal literature is considered to be the sole authority of Indonesian literature, Indonesian literary life is not healthy, there needs to be opposition to universal literature. The heterodoxa of contextual literature still do not match the doctrine of univers al literature. Moreover, universal literature has "become" national literature or Indonesian literature.

Wiji Thukulemerged or practiced his literature when the universal literary doxa was very strong that he experienced a failure which was marked by the absence of recognition from national literary agents or Indonesian literature as universal literature. This caused Wiji Thukul to change the position of his literary practice.

\section{Refferences}

[1] D. Gartman, "Bourdieu's theory of cultural change: Explication, application, critique," Sociol. Theory, vol. 20, no. 2, pp. 255-277, 2002.

[2] P. Bourdieu, Choses Dites: Uraian dan Pemikiran. Yogyakarta, 2011.

[3] P. Bourdieu, Arena Produksi Kultural. Yogyakarta: Pustaka Pelajar, 2010.

[4] P. Bourdieu, The Field of Cultural Production: Essays on Art and Literature. Columbia: Columbia University Press, 1993.

[5] M. Grenfell, Pierre Bourdieu : key concepts. Durham: Acumen, 2012.

[6] K. Y. Karnanta, "Paradigma Teori Arena Produksi Kultural Sastra: Kajian Terhadap Pemikiran Pierre Bourdieu," Poet. J. Ilmu Sastra, vol. 1, no. 1, pp. 1-11, 2013.

[7] A. Zulkifli;, S. J. Suyono, and P. Setiadi, Wiji Thukulteka-teki orang hilang. Jakarta: Kepustakaan Populer Gramedia, 2019.

[8] P. Bourdieu, Arena Produksi Kultural: Sebuah Kajian Sosiologi Budaya. Kasihan Bantul Yogjakarta: Kreasi Wacana, 2016

[9] W. J. Creswell, Research Design: Pendekatan, Metode Kualitatif, Kuantitatif, dan Campuran. Yogyakarta: Pustaka Pelajar, 2017.

[10] A. Heryanto, Perdebatan Sastra Kontekstual. Jakarta: Rajawali Press, 1985.

[11] A. Budiman, Kebebasan, Negara, Pembangunan. Kumpulan Tulisan 1965 - 2005. Jakarta: Pustaka Alvabet dan Freedom Institute, 2006.

[12] A. Heriyanto, "Masihkan Politik Jadi Panglima? Politik Kesusastraan Indonesia Mutahir," Prisma, Jakarta, 1984.

[13] P. Allen, S. Sindhunata, and Y. B. Mangunwijaya, Menjadigenerasi pasca-Indonesia: kegelisahan Y.B. Mangunwijaya. Yogyakarta: Kanisius, 1999.

[14] K. Y. Karnanta, "Sastra 'Mungkin': Kontestasi Simbolik Andrea Hirata Dalam Arena Sastra Indonesia,” J. Poet., vol. 3, no. 2, pp. 91-101, 2015. 